\title{
5: $112118469-112209533$
}

National Cancer Institute

\section{Source}

National Cancer Institute. 5:112118469-112209533. NCI Thesaurus. Code C41699.

Physical location of APC_Gene 